\title{
MEDIAÇÃO COMO INSTRUMENTO PARA SOLUÇÃO DE CONFLITOS: DIREITO FUNDAMENTAL DE ACESSO À JUSTIÇA
}

\author{
MEDIATION AS AN INSTRUMENT FOR SETTLEMENT OF CONFLICTS: \\ FUNDAMENTAL RIGHT OF ACCESS TO JUSTICE
}

\begin{abstract}
Elaine Cler Alexandre dos Santos
Doutoranda em Desenvolvimento Local, com área de concentração em Contexto de Territorialidade. Mestre em Direito, área de concentração, Empreendimentos Econômicos, Desenvolvimento e Mudança Social (2007). Especialista em Direito do Trabalho (2000).

Graduada em Direito pela Faculdade de Direito da Alta Paulista de TUPÃ/SP (1995).

Atualmente, exerce a coordenação do Curso de Direito da Universidade Católica Dom

Bosco-UCDB, além de professora titular da cadeira de DIREITO PROCESSUAL DO

TRABALHO na UCDB, no curso de Pós-Graduação. Mediadora judicial do Tribunal de

Justiça do Mato Grosso do Sul - TJMS. Atua principalmente na área trabalhista, como advogada e docente na graduação da UCDB, desde 2000 e na Pós-Graduação desde 2007.

E-mail:elainecler121314@gmail.com
\end{abstract}

Pedro Pereira Borges

Doutor em Ciências Sociais pela Pontifícia Universidade Católica de São Paulo (2012). Possui graduação em Pedagogia pela Universidade Católica Dom Bosco (2003), graduação em Teologia pelo Instituto Santo Tomás de Aquino (2001), graduação em

Filosofia - Faculdades Unidas Católicas de Mato Grosso (1989), mestrado em Ciências Sociais pela Pontifícia Universidade Católica de São Paulo (2007). Atualmente trabalha no

Programa de Pós-Graduação em Desenvolvimento Local da da Universidade Católica Dom Bosco. E-mail:pedropborges@gmail.com

Recebidoem: 31/07/2017

Aprovadoem: 14/03/2018

RESUMO: O presente estudotem por objetivo apresentar o instituto da mediação, como forma de eliminar a necessidade de uso da via judicial para resolução dos conflitos e contribuir para a efetivaaplicaçãodesseprocedimentoem todo o país. A metodologia utilizada foi a bibliográfica, comseleção de livros e artigos, sobre o tema. A mediação como meio alternativo de resolução de conflitos pode contribuir também para o aperfeiçoamento da legislaçãojá existente. A mediação surge como uma alternativa de jurisdição, reconhecida pela Constituição Federal como instrumento legal capaz de dirimir os conflitos de interesse, uma vez frustrada eventual negociação entre partes litigantes. $\mathrm{O}$ instituto da mediação, entretanto, ainda é pouco utilizado, oumesmodesconhecido, pela maioria da população, fruto principalmente da falta de informação e de incentivo nautilização de meiosextrajudiciais de resolução de contendas. A utilização de meios alternativos como a mediaçãoserve para, se não resolver, pelo menos tentar minimizar o colapso da viajurisdicional de solução de conflitos agravado pelo aumento crescente do número de demandas nas diversas esferas do Poder Judiciário.

Palavras-Chave: Conflito; Mediação; Solução; Acesso à Justiça.

ABSTRACT: The present study aims to present the Institute of mediation as a way to eliminate the need to use the judicial process for conflict resolution and contribute to the effective 
application of this procedure across the country. The methodology used was the essay, with selection of books and articles on the theme. The mediation as alternative means of conflict resolution can also contribute to the improvement of the existing legislation. Mediation is an alternative jurisdiction, recognized by the Federal Constitution as a legal instrument capable of settling the conflicts of interest, once frustrated possible negotiation between the litigant parties. The Institute of mediation, however, is still little used, or even unknown, by the majority of the population, mainly fruit of the lack of information and to encourage the use of non-judicial means of resolving disputes. The use of alternative means such as mediation serves to, if not resolve, at least try to minimize the collapse of via Court resolving conflicts aggravated by the increase in the number of demands in different spheres of the judiciary.

Key Words: Conflict; Mediation; Solution; Access to justice.

SUMÁRIO: 1. INTRODUÇÃO; 2 JUSTIÇA X DIGNIDADE DA PESSOA HUMANA; 3 O DIREITO FUNDAMENTAL DE ACESSO À JUSTIÇA; 4 MEDIAÇÃO; CONSIDERAÇÕES FINAIS; REFERÊNCIAS.

\section{INTRODUÇÃO}

2

No convívio em sociedade, os conflitos de interesses são fenômenos naturais, que podem ser resolvidos pelas próprias partes em litígio, através de órgãos estatais investidos de jurisdição ou de forma amigável por meio de soluções alternativas de jurisdição. Atualmente, o sistema jurisdicional estatal é o mais adotado por aqueles que pretendem solucionar os conflitos de interesse.

Ocorre que, à margem do sistema tradicional existem meios paraestatais de resolução de contendas, criados pelo legislador, no intuito de proporcionar às partes em litígio soluções alternativas para resolver os conflitos de interesse.

A demora do Judiciário na prestação de uma tutela jurisdicional de qualidade incentiva o jurisdicionado a buscar soluções alternativas que assegurem aquilo que o sistema estatal não está sendo capaz de oferecer de maneira satisfatória ao cidadão, ou seja, a aplicação de uma tutela jurisdicional de qualidade, célere e eficaz.

Os meios alternativos de resolução de conflitos podem auxiliar o sistema estatal a melhorar a qualidade do serviço prestado, uma vez que retiram do Estado o monopólio da jurisdição e contribuem, dessa forma, para a diminuição da carga processual do Judiciário.

A utilização de meios alternativos para resolver controvérsias é cada vez mais comum em países como o Brasil, onde o sistema estatal funciona de forma deficiente e não atende às necessidades do jurisdicionado. Contudo, a aplicação de meios extrajudiciais de resolução de conflitos tem ocorrido de forma lenta, resultado, principalmente, da falta de publicidade.

Dentre os procedimentos alternativos extrajudiciais, existe aquele em que as partes, em comum acordo, indicam uma terceira pessoa para resolver a lide, através de regras procedimentais próprias, assegurado o devido processo legal e a observância dos preceitos legais. A mediação se destaca pela simplicidade, informalidade, celeridade, caráter sigiloso e principalmente pelo consenso das partes quanto à escolha do(s) árbitro(s) e do juízo para a solução da lide, garantindo maior eficácia na prestação da tutela jurisdicional.

Nos países em desenvolvimento como o Brasil, onde os meios extrajudiciais de resolução de conflitos ainda são pouco conhecidos pela maioria da população, a mediação surge como uma alternativa para o problema da morosidade na tramitação dos processos em diferentes esferas do Judiciário. 
O problema investigado resume-se: a mediação pode ser usada para garantir maior celeridade na solução das lides e desonerar o judiciário, porquanto as partes não precisam entrar com a ação, solucionando o caso rapidamente, garantindo a satisfação de ambas as partes?

A mediação como meio alternativo de resolução de conflitos pode contribuir também para o aperfeiçoamento da legislação já existente. Quando se discute a aplicação de determinado procedimento, seja na área jurídica ou em qualquer outra área, o objetivo principal é sempre o enriquecimento da matéria através do confronto de opiniões, no sentido de ampliar os conhecimentos sobre o assunto e criar possibilidades reais de aplicação do procedimento no caso concreto. É o que ocorre também com relação à mediação.

É dentro desse novo contexto jurídico institucional que o presente estudo tem por objetivo apresentar o instituto da mediação, como forma de eliminar a necessidade de uso da via judicial para resolução dos conflitos e contribuir para a efetiva aplicação desse procedimento em todo o país.

A metodologia utilizada foi a bibliográfica, com seleção de livros e artigos, sobre o tema.

$\mathrm{O}$ artigo está estruturado em cinco partes, sendo: introdução; justiça x dignidade da pessoa humana; direito fundamental de acesso à justiça; mediação e as considerações finais.

\section{JUSTIÇA X DIGNIDADE DA PESSOA HUMANA}

OEstado Democrático de Direito, tem como base de seu conceito, a noção de governo do povo, que nasceu das lutas contra o absolutismo, através da afirmação dos direitos naturais da pessoa humana. Movimento esse que se transpôs do plano teórico para o prático com três grandes movimentos político-sociais (BOBBIO, 1992).

A luta contra o absolutismo, que caracteriza a segunda fase do Estado Moderno, representou a luta da classe burguesa para garantia de direitos sobre os meios de produção, ou seja, a propriedade privada (STRECK; MORAIS, 2003).

Bobbio (1992) acredita que com a Revolução Francesa, iniciou-se uma nova época da história, na qual a meta era firmar direitos naturais, sendo o principal a liberdade, seguido pela igualdade diante da lei, enquanto uma sua ulterior determinação. Ainda, nesse sentido,

Só assim se descobre que o homem, antes de ter direitos civis que são o produto da história, tem direitos naturais que os precedem; e esses direitos naturais são o fundamento de todos os direitos civis. Mais precisamente: são direitos naturais os que cabem ao homem em virtude de sua existência. A esse gênero pertence todos os direitos intelectuais, ou direitos de mente, e também todos os direitos de agir como indivíduo para o próprio bem-estar e para a própria felicidade que não sejam lesivos aos direitos naturais dos outros. Distinguiam-se três formas de governo: o fundado na superstição, o fundado na força, e um terceiro, fundado no interesse comum, que ele chamava de governo da razão (BOBBIO, 1992, p. $88)$.

Afirma Bobbio que "o fato é que foi a Revolução Francesa que constituiu, por cerca de dois séculos, o modelo ideal para todos os que combateram pela própria emancipação e pela própria libertação do próprio povo" (BOBBIO, 1992, p. 92). Dessa forma,

O núcleo doutrinário está contido nos três artigos iniciais: o primeiro refere-se à condição natural dos indivíduos que precede a formação da sociedade civil; o segundo, à finalidade da sociedade política, que vem depois (se não 
cronologicamente, pelo menos axiologicamente) do estado de natureza; o terceiro, ao princípio de legitimidade do poder que cabe à nação (BOBBIO, 1992, p. 93).

Em relação à segunda fase do Estado Moderno ${ }^{1}$, Silva (1992) afirma que foram à concepção dos direitos naturais e o pensamento cristão, as principais fontes de inspiração para que houvesse a declaração dos direitos fundamentais. Contudo, a afirmação dos direitos fundamentais no nascedouro do Estado Democrático de Direito está restrita aos direitos individuais, que representam a luta de uma classe: a classe burguesa; ou seja, são valores voltados à garantia de liberdade e da propriedade privada.

Afirma Silva que,

[...] fundada na insuficiente e restrita concepção das liberdades públicas, não atina com a necessidade de envolver nessa problemática também os direitos econômicos, sociais e culturais, aos quais se chamam brevemente de direitos sociais (SILVA, 1992, p. 158).

Com relação as declarações dos direitos, Silva salienta que,

Temos, pois, que ampliar nossa visão do problema para admitir outras fontes de inspiração das declarações de direito, sem deixar de reconhecer que as primeiras abeberaram no cristianismo e no jusnaturalismo sua ideia do homem abstrato. Mas não é uma observação correta essa de atribuir, ao surgimento de uma nova ideia de direito, tão profundamente revolucionária, inspiração de natureza basicamente ideal, sem levar em conta as primeiras históricas objetivas, que, na verdade, constituem a sua fundamentação primeira. As doutrinas e concepções filosóficas têm relevância enorme no processo. Mas elas próprias são condicionadas por aquelas condições materiais. Surgem precisamente para ordená-las numa compreensão ideológica coerente, interpretando-as, para definir-lhes as leis a elas imanentes, já que, em tais momentos agudos da evolução social, se percebe a superação de situações caducas pelo despontar de algo novo (SILVA, 1992, p. 158)..

Este momento histórico representa a conquista dos direitos fundamentais voltados ao interesse da burguesia. Nesse sentido, Silva afirma que

As declarações de direitos assumiram, inicialmente, a forma de proclamações solenes em que, em articulado orgânico especial, se enunciam os direitos. Depois, passaram a constituir o preâmbulo das constituições, na França

\footnotetext{
1 “A primeiracaracterística do Estado Moderno é essaautonomia, essa plena soberania do Estado, a qualnãopermitequesuaautoridadedependa de nenhumaoutraautoridade. A segunda é a distinção entre o Estado e sociedade civil, quevaievidenciar-se no séc. XVII, principalmentenaInglaterra, com a ascensão da burguesia. O Estado se tornaumaorganizaçãodistinta da sociedade civil, emborasejaaexpressãodesta. Uma terceiracaracterísticadiferencia o Estado emrelaçãoàquele da IdadeMédia. O estado medieval é propriedade do senhor, é um Estado patrimonial. O senhor é dono do território e de tudo o quenele se encontra (homens e bens). No Estado Moderno, pelocontrário, existeumaidentificaçãoabsoluta entre o estado e o monarca, o qualrepresenta a soberaniaestatal. Maistarde, em fins de 1600, o reifrancêsafirmava " $L$ ' etatc'estmoi", no sentido de queeledetinha o poderabsoluto, mas também de queele se identificavacompletamente no Estado". SILVA, José Afonso.Curso de direitoconstitucionalpositivo.8. ed. São Paulo: Malheiros, 1992, p. 156.
} 
especialmente. Atualmente, ainda que nos documentos internacionais assumam a forma das primeiras declarações, nos ordenamentos nacionais integram as constituições, adquirindo o caráter concreto de normas jurídicas positivas constitucionais, por isso, subjetivando-se em direito particular de cada povo [...], configuram declarações constitucionais de direito, o que tem conseqüência jurídica prática relevante [...] (SILVA, 1992, p. 161).

Até o advento do Estado Democrático de Direito, o Estado Moderno caracterizava-se pela afirmação exclusiva dos seguintes elementos formais: o governo, o poder, a autoridade ou o soberano. Essa primeira fase do Estado Moderno nasce das deficiências da sociedade política medieval, as quais determinaram aqueles elementos como características fundamentais do Estado Soberano. O Estado com essa nova feição, "procura ligar o Poder a uma função e para que formasse o conceito de Estado era necessário que a potência, que é a possibilidade de ser obedecido se reforçasse com a autoridade, que é uma qualificação para dar a ordem" (STRECK; MORAIS, 2003, p. 27).

A ruptura do Estado Absolutista advém com as históricas Revoluções: Francesa, Inglesa e Americana. A Revolução Francesa é considerada, desde sua ocorrência há duzentos anos, o mais importante acontecimento da história contemporânea. Baseada em ideais iluministas, o lema "Liberdade, Igualdade, Fraternidade", ficou conhecida por todo mundo. A explicação para toda essa significativa importância à essa revolução é que ela é uma espécie de marco fundamental da sociedade capitalista (MICELI, 1994). Afirma Miceli,

Além disso, a Revolução Francesa é considerada "o modelo clássico de revolução democrático-burguesa". Modelo, talvez porque pode e deve servir de exemplo ou mesmo de matriz para outros movimentos revolucionários, o que demonstra profunda ignorância das condições peculiares a cada época ou espaço. Clássico, talvez porque resistiu à deteriorização que normalmente atinge os acontecimentos históricos, mantendo e mesmo elevando seu valor com o passar dos anos. Democrático, talvez porque suas palavras de (liberdade, igualdade, fraternidade) tencionavam assegurar princípios de respeito aos direitos de cada um, como bem supremo formador da nação moderna. Finalmente, burguesa certamente porque - como sua própria história demonstrou há seu tempo - sua reprodução imaginária ajuda a deter propostas de mudanças efetivas. Por tudo isso, deve perdurar intocável, auxiliando, inclusive, a preservar os valores de liberdade, igualdade e fraternidade - sempre de acordo com o conceito burguês dessas palavras, o que também impede que elas corram o risco de virar realidade (MICELI, 1994, p. 50-51).

Completa Streck que, com "a Revolução Francesa, a burguesia inaugura seu poder político com classe: acaba ela de suprir a contradição com o passado" (2003, p. 49).

A Revolução Inglesa também chamada "Revolução Puritana" do século XVII, foi o confronto entre a Monarquia e o Parlamento, agravado pelas divergências religiosas. Os realistas em sua maioria eram anglicanos e católicos e seus adversários eram puritanos (calvinistas) defensores dos direitos à propriedade e sua livre exploração. Porém, os dois grupos pertenciam, basicamente, às mesmas classes sociais: a alta nobreza, a gentry e a burguesia (STRECK; MORAIS, 2003).

Assim diz Miceli que,

[...] na Revolução Inglesa contou mais a crise que atingia o velho regime do que a vontade consciente de uma burguesia ainda pouco numerosa, longe de representar uma força coesa e identificada por aspirações comuns e claras para 
todos. Umas vezes, apoiando o rei e dependendo de seu apoio; outras, combatendo-o; ora, insuflando as massas; ora, esforçando-se por contê-la. Nessas idas e vindas, a burguesia e os novos proprietários foram conquistando espaço e poder. Por todas essas razões, Chistopher Hill afirmou que "a Revolução Inglesa (de 1640) não foi feita ao talante de ninguém: aconteceu", concluindo, ironicamente, como OliCrowell falasse pela sua boca, que "a revolução foi um trabalho de Deus, porque não foi feita pela vontade dos homens e porque foi um momento de virada na história humana" (MICELI, 1994, p. 42-43)

A Revolução Americana de 1776, segundo Karnal (1999), foi a primeira grande rebelião do mundo colonial contra uma metrópole, no caso o reino da Grã-Bretanha. Os colonos mostraram-se cada vez mais decididos a conseguirem sua independência, se travando, então, as primeiras batalhas. Complementa o autor que,

Os problemas que a Declaração de Independência enumera já são nossos conhecidos; as leis mercantilistas, as guerras que prejudicavam os interesses dos colonos, a existência de tropas que os colonos deviam sustentar, etc. A paciência dos colonos, sua calma e ponderação são destacadas em oposição à posição intransigente e autoritária do rei da Inglaterra, no caso, Jorge III (KARNAL, 1999, p. 66.).

Com relação à segunda versão do Estado Moderno - o modelo liberal e o triunfo da burguesia, Streck salienta, que o "contratualistaRosseau é que exercerá grande influência nos revolucionários franceses que inauguraram, em 1789, uma nova fase do Estado Moderno" (STRECK; MORAIS, 2003, p. 46). Nesse sentido, observa Streckque

Com efeito, enquanto instituição centralizada, o Estado, em sua primeira versão absolutista, foi fundamental para os propósitos da burguesia no nascedouro do capitalismo, quando esta, por razões econômicas, "abriu mão" do poder político, delegando-o ao soberano, concretizando-se mutatis mutandis, aquilo que Hobbes sustentou no Leviatã. Na virada do século XVII, entretanto, essa mesma classe não mais se contentava em ter o poder econômico; queria, sim, agora, tomar para si o poder político, até então privilégio da aristocracia. Como bem lembra Bonavides, a monarquia absolutista não foi jamais à burguesia politicamente no poder. A contradição enfeixada pelo poder monárquico absoluto no seu comportamento perante as classes sociais conduz por vezes àquele equívoco de interpretação. A monarquia favoreceu, mormente na área econômica. Já lhe era impossível represá-los. A monarquia absoluta, já sem meios de qualquer ação impeditiva à expansão capitalista da primeira idade do Estado Moderno, entra a estimulá-la com a adoção da política mercantilista, política de reis sequiosos de fundos com que manter a burocracia e os exércitos permanentes, política da qual a aristocracia tirava também sua fatia de participação ociosa, mas, sobretudo política, verdadeira, profunda, necessária, dos interesses arraigados da classe mercantil e industrial (STRECK; MORAIS, 2003, p. 46).

Por outro lado, “é em Locke que se vê a constituição do perfil do liberalismo político sustentado a necessidade de limitação do poder e das funções do Estado", cuja doutrina, a do contrato social, "tornou-se um importante componente teórico para os revolucionários de então. A 
reivindicação de uma Constituição embasava-se exatamente na tese de que o contrato social encontra sua explicação na constituição" (STRECK; MORAIS, 2003, p. 49).

Afirmam Streck e Morais (2003) que, o contratualismo tem como principal ideia o indivíduo, seja em Hobbes, seja em Locke, já que o consentimento advinha do próprio indivíduo e representou a apoteose do direito natural no sentimento individualista moderno. Entronizando o direito de resistência, ampliou o princípio individualista de vontade e consentimento em lugar de tradição e é a principal característica de legitimidade em política liberal.

Por liberalismo entende-se o movimento de ideias que passa através de diversos autores consagrados como: Locke, Montesquieu, Kant, Adam Smith, e vários outros, como uma teoria econômica, que defende a economia de mercado; como teoria política, defensor do Estado que governe o menos possível (BOBBIO, 1992). Ainda assim,

Quando se discorre sobre liberalismo, faz-se referência a um complexo de ideias que dizem respeito à condução e à regulamentação da vida prática, em particular da vida associada. Já que afirmação de liberdade de um se resolve sempre na limitação da liberdade de outro, num universo de bens consumíveis e de recursos limitados como é aquele no qual estão destinados a viver os homens, o postulado ético da liberdade individual vale como princípio inspirador, mas deve ser aplicado a casos concretos; daí que o problema que a doutrina liberal está chamada a resolver, como doutrina econômica e política, é o de tornar possível a coexistência das liberdades, o que se traduz na formulação e aplicação de regras práticas de conduta, e em definitivo na proposta de um certo sistema econômico e de um certo sistema político (BOBBIO, 1992, p. 130).

OEstado Democrático de Direito é a noção de governo do povo, que nasceu das lutas contra o absolutismo, através da afirmação dos direitos naturais da pessoa humana. Movimento esse que se transpôs do plano teórico para o prático com três grandes movimentos político-sociais como a Revolução Francesa, a Revolução Inglesa e a Revolução Americana, lutas essas que caracterizam a segunda fase do Estado Moderno, principalmente com a Revolução Francesa, pois daí iniciara-se, uma nova época da história. Foi nesta fase que o Estado Moderno concedeu à concepção dos direitos naturais, o pensamento cristão, e as principais fontes de inspiração para que então houvesse a declaração dos direitos fundamentais (BOBBIO, 1992).

Após o término da primeira guerra mundial, novos direitos fundamentais foram reconhecidos. Os direitos econômicos e sociais que não eliminam nem negam as liberdades públicas, mas a elas se somam. Assim faz-se necessário, lembrar alguns fatos e apontar algumas ideias que marcaram o século XIX e os primeiros anos do Século XX, para se ter uma noção da importância do direito à igualdade material para a realização da cidadania. Paralelamente ao avanço do liberalismo político e econômico, o período acima referido assistiu à deterioração do quadro social, particularmente nos Estados mais desenvolvidos da Europa ocidental e nos Estados Unidos (FERREIRA, 2000).

Para Ferreira,

Este desenvolvimento foi motivado pelas ideias do liberalismo econômico livre iniciativa num mercado concorrencial - e propiciado pelas instituições Estado abstencionista - e regras decorrentes das revoluções liberais. Teria sido impossível sem a abolição das corporações de ofício, sem a liberdade de indústria, comércio e profissão, sem a garantia da propriedade privada etc. Por outro lado, esse processo provocou um acréscimo súbito de riqueza, que atingiu níveis jamais vistos. Mas esta riqueza ficou concentrada nas mãos dos empresários, ou da classe burguesa se se preferir. E verdade, porém, que isto 
vale globalmente falando, pois os ciclos econômicos, as crises, frequentemente retiravam tudo daquele que em um momento haviam sido imensamente ricos. Tudo isto é sabido (FERREIRA, 2000, p. 42).

Em contrapartida, afirma Dallari (2003) que a classe trabalhadora se viu numa situação de miséria. Não havia mais a proteção corporativa, e o poder público se omitia. O trabalho era uma mercadoria como qualquer outra, sujeito à lei da oferta e da procura e a máquina reduzia a necessidade de empregados além dos baixos salários. Tal situação era um agrave ameaça à estabilidade das instituições liberais, e consecutivamente, à continuidade do processo de desenvolvimento econômico, que necessitava ser superada, suscitando assim uma batalha política e intelectual.

Sustenta Ferreira que,

[...] essa exigência foi-se intensificando à medida que maior número de trabalhadores acediam aos direitos políticos - voto e elegibilidade - em razão da redução do censo para tanto exigido. Duas orientações se formaram: uma que visava a reconciliar com as demais classes e com o Estado, postura esta reformista do positivismo, do socialismo democrático, do cristianismo social, que mais tarde levou aos direitos econômicos e sociais. Ainda em posição oposta assumiram os grupos revolucionários, que para estes, só a extinção das classes "exploradoras" do Estado "burguês", para os socialistas radicais, de todas as classes e do Estado para Marx e seus seguidores, para os anarquistas, é que seria a solução (FERREIRA, 2000, p. 43-44).

O movimento reformista ganhou um forte apoio com a chamada doutrina social da igreja a partir da encíclica Rerumnovarum, editada em 1891 pelo Papa Leão XIII, que retoma, de São Tomás de Aquino, a tese do bem comum, da essência na "vida humana digna", bem como a doutrina clássica do direito natural, ao mesmo tempo em que sublinha a dignidade do trabalho e do trabalhador, culminando com a afirmação de direitos que exprimem as necessidades mínimas de uma vida consentânea com a dignidade do ser humano, criado à imagem e semelhança de Deus. Daí o direito ao trabalho, à subsistência, à educação, etc. (FERREIRA, 2000).

Conforme Ferreira (2000, p. 45) "não faz dúvida, entretanto, que o principal documento da evolução dos direitos fundamentais para a consagração dos direitos econômicos e sociais foi a Constituição francesa de 1848 ". Sendo assim se posiciona

Esse 1848 foi na Europa um ano de graves conflitos, de "revoluções", uma dos quais foi a que derrubou na França a monarquia orleonista. Ora, um elemento importante nesses movimentos, e particularmente no que ocorre em Paris, foi à atuação dos trabalhadores e dos empregados. A conotação social da revolução que levou à segunda república é nítida. A Constituição então elaborada, promulgada em 4 de novembro, é precedida de um preâmbulo e contém um capítulo no qual se enunciam os direitos por ela garantidos (FERREIRA, 2000, p. 46).

A constituição mexicana de 1917, conforme afirma Ferreira (2000), é a Constituição considerada por alguns como o marco consagrador de uma nova concepção dos direitos fundamentais. O que essa carta apresentou como novidade foi o nacionalismo, a reforma agrária e a hostilidade em relação ao poder econômico, e não propriamente o direito ao trabalho, mas um elenco dos direitos do trabalhador. 
Na parte XIII do Tratado de Versalhes, segundo Ferreira (2000), de 28 de junho de 1919, se definiram as condições de paz entre os Aliados e a Alemanha. Nele encontra-se a chamada Constituição da Organização Internacional do Trabalho (OIT) na qual se consagram os direitos do trabalhador, direitos sociais vistos como fundamentais e obrigatórios para todos os Estados signatários do referido Tratado.

Com relação à Constituição alemã de 1919, Ferreira (2000) afirma que essa surgiu, pois gravíssima era a situação da Alemanha de qualquer ângulo que fosse encarada, ao final da primeira guerra mundial. As instituições políticas estavam acabadas, a situação social extremamente agravada e as forças de ordem desmoralizadas. Assim não havia condições para a Assembleia Constituinte estabelecer um novo quadro Constitucional em Berlim. Por isso, reuniram se em Weimar, de onde se originou a Constituição para a Alemanha republicana, da qual seu ponto mais relevante foi quando abordou a respeito dos Direitos e deveres fundamentais dos alemães que dedica ao indivíduo, à vida social, à religião e sociedades religiosas, à instrução e estabelecimento de ensino e à vida econômica.

Consagrados embora os direitos sociais, desde 1919, foram objetos de reiteração depois da segunda guerra mundial, não mudando o seu objetivo de estabelecer a freedomfromwant. De modo sistemático

[...] esses direitos vieram a ser tratados em Constituições, como a brasileira de 1946, a italiana de 1947, Títilos II - Relações Ético-Sociais (onde se inscrevem os direitos à saúde e à educação) e III - Relações Econômicas (onde se arrolam o direito ao trabalhado, o direito de greve, a liberdade sindical etc.) E, de modo geral, em todas as que foram editadas após o conflito (FERREIRA, 2000, p. 53).

Toda essa evolução encontrou escopo na Declaração Universal dos Direitos do Homem, promulgada em 10 de dezembro de 1948. Nesse sentido,

Com efeito, nela estão a liberdade pessoal, a igualdade, com a proibição das discriminações, os direitos à vida e à segurança, a proibição das prisões arbitrárias, o direito ao julgamento pelo juiz natural, a presunção de inocência, a liberdade de ir e vir, o direito de propriedade, a liberdade de pensamento e de crença, inclusive a religiosa, a liberdade de opinião, de reunião, de associação, mas também direitos "novos" como o direito de asilo, o direito a uma nacionalidade, a liberdade de casar, bem como direitos políticos - direito de participar da direção do país -, de um lado, e, de outro, os direitos sociais - o direito à seguridade, ao trabalho, à associação sindical, ao repouso, aos lazeres, à saúde, à educação, à vida cultural -, enfim, num resumo de todos estes - o direito a um nível de vida adequado (o que compreende o direito à alimentação, ao alojamento, ao vestuário etc.) numa palavra-, aos meios de subsistência (FERREIRA, 2000, p. 53).

Segundo Dallari (2003), após a II Guerra Mundial, o problema dos direitos fundamentais da pessoa humana foi posto em debate novamente. Foi em 26 de junho de 1945, que se aprovou a Carta das Nações Unidas, destinada a fornecer a base jurídica para a permanente ação conjunta dos Estados, em defesa da paz mundial. Mas a experiência já havia deixado bem evidente que não pode existir paz onde não houver justiça social, surgindo, portanto, a ideia de uma Declaração de Direitos que fixasse as diretrizes para a reorganização dos Estados. Em 1946 foi iniciado o trabalho de elaboração desse documento, que foi aprovado na terceira sessão ordinária 
da Assembleia Geral das Nações Unidas, em 10 de dezembro de 1948, recebendo o nome de Declarações Universal dos Direitos do Homem.

Ainda no contexto histórico, sob a pressão das nações totalitárias em relação aos outros países, a Organização das Nações Unidas- ONU pretendia a associação de todos os países para proteger e garantir os direitos fundamentais do homem nos países vindos da calamidade da Segunda Guerra, estabelecer condições para que contratos e outras fontes do direito internacional sejam mantidas e por fim, promover o progresso social dentro de uma liberdade mais ampla ${ }^{2}$. Sobre esse episódio, Comparato explica:

As consciências se abriram, enfim, para o fato de que a sobrevivência da humanidade exigia a colaboração de todos os povos, na reorganização das relações internacionais com base no respeito incondicional à dignidade humana. (COMPARATO, 2008, p. 214) (grifou-se)

Nesse sentido, Ana Paula de Barcellosexplica que foi comum para as Constituições promulgadas após a Segunda Guerra a institucionalização dos princípios que garantiam a humanização, dentre eles a dignidade da pessoa humana.

[...] foi a introdução nos textos de cláusulas, juridicamente obrigatórias para toda e qualquer maioria de plantão, veiculando de forma expressa a decisão política do constituinte (i) por determinados valores fundamentais orientadores da organização política e (ii), em maior ou menor extensão, por certos limites, formas e objetivos dirigidos à atuação política do novo Estado, com a finalidade de promover a realização desses valores. Sob a forma de princípios, os valores passaram a ser as ideias centrais das Cartas constitucionais (BARCELLOS, 2008, p. 26).

No Brasil, a dignidade da pessoa humana está representada na Constituição Federal de 1988 em forma de princípio basilar.

Filosoficamente, Immanuel Kanttem grande influência no que se compreende por dignidade, pois foi o primeiro a reconhecê-lo como um atributo humano. Em sua obra "Fundamentação da Metafísica dos Costumes", o autor entende que a dignidade impede que seja atribuído algum valor econômico ao homem, portanto, faz com que os humanos hajam de forma autônoma, e realizando suas vontades constroem suas personalidades individualmente, o que o torna insubstituível ou impagável. Em trecho do referido livro:

No reino dos fins, tudo tem ou um preço ou uma dignidade. Quando uma coisa tem preço, pode ser substituída por algo equivalente; por outro lado, a coisa que se acha acima de todo preço, e por isso não admite qualquer equivalência, compreende uma dignidade (KANT, 1980, p. 65).

Kant explica o que entende por dignidade, afirmando que essa se constitui do valor sentimental e emocional que se atribui à uma determinada satisfação, é um valor íntimo, que cada um atribui à um determinado estado de ser, veja-se

\footnotetext{
${ }^{2}$ BRASIL.DECRETO $\mathbf{n}^{\mathbf{0}} \mathbf{1 9 . 8 4 1}$, de 22 de outubro de 1945.Disponívelem: http://www.planalto.
} gov.br/ccivil_03/decreto/1930-1949/d19841.htm.

Revista de Direito Brasileira | São Paulo, SP | v. 20 | n. 8 | p. 146-173 |Mai./Ago. 2018 
$\mathrm{O}$ que se relaciona com as inclinações e necessidades gerais do homem tem um preço venal; aquilo que, mesmo sem pressupor uma necessidade, é conforme a um certo gosto, isto é a uma satisfação no jogo livre e sem finalidade das nossas faculdades anímicas, tem um preço de afeição ou de sentimento (Affektionspreis); aquilo porém que constitui a condição só graças à qual qualquer coisa pode ser um fim em si mesma, não tem somente um valor relativo, isto é um preço, mas um valor íntimo, isto é dignidade(KANT, 1980, p. $65)$.

Ingo Wolfgang Sarlet (2005) ensina que todos possuem dignidade indistintamente e não poderão perdê-la por motivo algum. No mesmo sentido, Luís Roberto Barroso afirma que:

O princípio da dignidade da pessoa humana identifica um espaço de integridade moral a ser assegurado a todas as pessoas por sua só existência no mundo. É um respeito à criação, independente da crença que se professe quanto à sua origem. A dignidade relaciona-se tanto com a liberdade e valores do espírito como com as condições materiais de subsistência (BARROSO, p. 51).

Quanto à historicidade desse Princípio, desde o início da convivência dos povos em sociedade, inclusive por questões biológicas de perpetuação da espécie, os homens já se respeitavam ou não pelo modo de proceder de cada um, dessa forma, já se fazia presente a dignidade nas relações, mesmo que ainda não fosse reconhecida (RABINOVICH-BERKMAN, 2007).

\section{O DIREITO FUNDAMENTAL DE ACESSO À JUSTIÇA}

O Estado brasileiro ao avocar o dever de prestar a função jurisdicional, configurou esta prestação, fundamentalmente, apoiando-se em duas garantias inafastáveis, quais sejam: Direito de ação e de defesa dirigidos para as pessoas (direito de acesso à justiça) e a garantia do devido processo legal dirigido para o Estado-juiz (direito ao processo justo).

Isso se deve a uma razão especialmente simples, pois se o Estado deve prestar a função jurisdicional, é certo que as pessoas precisam ter acesso a exercer suas pretensões através de ação/defesa a ser processada perante o Estado-juiz. Sem tal acesso não haveria prestação jurisdicional alguma. Provocado o Estado-juiz, este deve manifestar-se de maneira devida, ou seja, através de um processo justo, equânime/democrático, ético onde as partes sejam ouvidas e possam materialmente influenciar na convicção do Estado-juiz.

A Constituição brasileira em vigor possui vários dispositivos a caracterizar a tutela constitucional da ação e do processo. A própria Constituição incumbe-se de configurar o direito processual não mais como mero conjunto de regras acessórias de aplicação do direito material, mas, cientificamente, como instrumento público de realização da justiça.

Nesse sentido, veja-se a lição de Cintra, Grinover e Dinamarco:

O direito de ação, tradicionalmente reconhecido no Brasil como direito de acesso à justiça para a defesa de direito individuais violados, foi ampliado, pela Constituição de 1988, à via preventiva, para englobar a ameaça, tendo o novo texto suprimido a referência a direito individuais. É a seguinte a redação do inc. XXXV do art. 5': "A lei não excluirá da apreciação do Poder Judiciário lesão ou ameaça a direito (CINTRA, GRINOVER, DINAMARCO, 2005, p. 80). 
Ao declarar que "A lei não excluirá da apreciação do Poder Judiciário lesão ou ameaça a direito", a Constituição Federal propõe uma aproximação da sociedade civil com a justiça para realização dos direitos através de criação por decisões judiciais de soluções justas. Essa garantia de acesso à justiça para obtenção de soluções justas através da participação no processo judicial deve ser entendida como proposta básica de uma sociedade democrática. Não existe democracia sem processo. Democracia é o regime dos procedimentos, onde o poder do povo é exercido por autoridades através de formas previamente conhecidas e aceitas. O procedimento é que permite o controle do exercício desse poder (CINTRA, GRINOVER, DINAMARCO, 2005).

Logo em seguida, no inciso LXXIV, a fim de equilibrar a desigualdade existente entre as diversas classes sociais, é previsto o direito à assistência jurídica integral e gratuita aos necessitados: "o Estado prestará assistência jurídica integral e gratuita aos que comprovarem insuficiência de recursos" (MESQUITA, 2013, p. 1).

De acordo com Mesquita (2013), trata-se de direito fundamental de segunda dimensão, por exigir uma atitude positiva do Estado, qual seja, a prestação de um serviço público - a assistência jurídica integral e gratuita. Tal dispositivo inovou em relação às Constituições anteriores, ao prever a assistência jurídica (judicial e extrajudicial) integral e gratuita aos necessitados. Além disso, a Constituição Federal determinou que a assistência jurídica integral e gratuita aos necessitados deverá ser prestada pelo Estado através do órgão denominado Defensoria Pública, o qual é composto por agentes públicos aprovados em concurso público e proibidos de exercer a advocacia fora das funções institucionais (Artigo 134, CF/1988).

Diante desse panorama, a Defensoria Pública é a instituição responsável por garantir o acesso à Justiça aos necessitados, fazendo com que eles recebam assistência jurídica e possam estar devidamente representados no processo judicial em todas as instâncias, dando efetividade, em última análise, aos princípios da igualdade e devido processo legal (MESQUITA, 2013).

Após a Carta Magna de 1988 o acesso à justiça para superação de conflitos teve grande incremento. Muitos comandos que instrumentalizam a tutela jurisdicional foram concebidos a partir da ideia de acesso à justiça, quais sejam: direito à assistência jurídica integral e gratuita e gratuidade dos atos necessários (MESQUITA, 2013).

Os Tribunais declararam de forma uníssona que pagamento de custas não poderia ser empecilho para a demanda e a jurisprudência vem contornando a exigência do pagamento de outras custas. A máxima realização do acesso à justiça, também decorreu da soma de esforços da Defensoria Pública, além de promotores, advogados, juízes, professores, defensores, servidores, estagiários de direito e demais pessoas que lidam com o direito (DE VITTO, s/d).

$\mathrm{O}$ acesso à justiça foi concretizando-se através de fases, como a assistência judiciária aos pobres, representação dos interesses difusos e acesso à representação em juízo pessoalmente, através de defensores públicos ou advogados dativos. Esta garantia evoluiu até ser compreendida como o mais básico dos direitos humanos, sendo requisito fundamental para qualquer sistema jurídico moderno que pretenda garantir e não apenas proclamar os direitos de todos (CINTRA, GRINOVER, DINAMARCO, 2010).

Veja-se precedente do Supremo Tribunal Federal ${ }^{3}$ :

\footnotetext{
${ }^{3}$ BRASIL. Supremo Tribunal de Justiça. AO 1.531-AgR, voto da Min. CármenLúcia, julgamentoem 3-6-09,
} Plenário, DJE de $1^{\circ}-7-09$. 
A Constituição da República estabeleceu que o acesso à justiça e o direito de petição são direitos fundamentais (art. 5\% inc. XXXIV, alínea a, e XXXV), porém estes não garantem a quem não tenha capacidade postulatória litigar em juízo, ou seja, é vedado o exercício do direito de ação sem a presença de um advogado, considerado 'indispensável à administração da justiça' (art. 133 da Constituição da República e art. $1^{\circ}$ da Lei n. 8.906/94), com as ressalvas legais. [...] Incluem-se, ainda, no rol das exceções, as ações protocoladas nos juizados especiais cíveis, nas causas de valor até vinte salários mínimos (art. $9^{\circ}$ da Lei $n$. 9.099/95) e as ações trabalhistas (art. 791 da Consolidação das Leis do Trabalho), não fazendo parte dessa situação privilegiada a ação popular.

A máxima realização da garantia de Acesso à Justiça está em consonância com a proclamação do dever de inafastabilidade do controle jurisdicional. É consabido que é constitucionalmente vedado a criação de quaisquer obstáculos para o cidadão na busca de acesso ao judiciário. Carece-se, ainda, do aperfeiçoamento e elaboração de mecanismos sintonizados com a realidade daquelas pessoas que estão afastados dos grandes centros. Nesse sentido, a inovação das tecnologias de informática e comunicação têm sido de grande utilidade porque encurtando distâncias aproximam o Estado das pessoas que buscam solução para lesão ou ameaça a direitos.

Veja-se precedente do Superior Tribunal de Justiça ${ }^{4}$ :

AÇÃO CIVIL PÚBLICA. APADECO. EFICÁCIA TERRITORIAL DA SENTENÇA. EXECUÇÕES INDIVIDUAIS DO TÍTULO. JUÍZO COMPETENTE. III - Considerando o princípio da instrumentalidade das formas e do amplo acesso à Justiça, desponta como um consectário natural dessa eficácia territorial a possibilidade de os agravados, consumidores titulares de direitos individuais homogêneos, beneficiários do título executivo havido na Ação Civil Pública, promoverem a liquidação e a execução individual desse título no foro da comarca de seu domicílio. Não há necessidade, pois, que as execuções individuais sejam propostas no Juízo ao qual distribuída à ação coletiva.

Embora o acesso efetivo à justiça venha sendo crescentemente aceito como um direito social básico nas sociedades modernas, o conceito de "efetividade" é algo vago. Afirmam Cappelletti e Garth (2002) que efetividade perfeita, no contexto de direito substantivo, poderia ser expressa como a completa "igualdade de armas" ou seja, a garantia de que a conclusão final depende apenas dos méritos jurídicos relativos das partes antagônicas, sem relação com diferenças que sejam estranhas ao Direito e que sendo assim afetam a afirmação e reivindicação dos direitos.

Nesse sentido, afirmam Cappelletti e Garth que,

Essa perfeita igualdade, naturalmente, é utópica. As diferenças entre as partes não podem jamais ser completamente erradicadas. A questão é saber até onde avançar na direção do objetivo utópico e a que custo. Em outras palavras, quantos dos obstáculos ao acesso efetivo à justiça podem e devem ser atacados? A identificação desses obstáculos, consequentemente, é a primeira tarefa a ser cumprida (CAPPELLETTI E GARTH, 2002, p. 15).

\footnotetext{
${ }^{4}$ BRASIL. Superior Tribunal de Justiça. AgRg no REsp 755429 / PR. AGRAVO REGIMENTAL NO RECURSO ESPECIAL 2005/0089854-4.
} 
Cappelletti e Garth (2002) identificam quatro obstáculos ao acesso à justiça, que depois de transpostos, se teria o efetivo acesso, sendo eles: As custas judiciais, a possibilidade das partes, os problemas especiais dos interesses difusos e as barreiras ao acesso: uma conclusão preliminar e um fator complicador.

Como primeiro obstáculo são as custas judiciais, afirmam que em geral,

A resolução formal dos litígios, particularmente nos tribunais, é muito dispendiosa na maior parte das sociedades modernas. Se é certo que o Estado paga os salários dos juízes e do pessoal auxiliar e proporciona os prédios e outros recursos necessários aos julgamentos, os litigantes precisam suportar a grande proporção dos demais custos necessários à solução de uma lide, incluindo os honorários advocatícios e algumas custas judiciais. $\mathrm{O}$ alto custo para as partes é particularmente óbvio sob o "Sistema Americano", que não obriga o vencido a reembolsar ao vencedor os honorários despendidos com seu advogado. Mas os altos custos também agem como uma barreira poderosa sob o sistema, mais amplamente difundido, que impõe ao vencido os ônus da sucumbência. Nesse caso, a menos que o litigante em potencial esteja certo de vencer - o que é de fato extremamente raro, dadas as normais incertezas do processo - ele deve enfrentar um risco ainda maior do que o verificado nos Estados Unidos. A penalidade para a vencido em países que adotam a princípio da sucumbência é aproximadamente duas vezes maior - ele pagará os custos do ambas as partes. Além disso, em alguns países, como a Grã-Bretanha, o demandante muitas vezes não pode sequer estimar o tamanho do risco - quanto lhe custará perder - uma vez que os honorários advocatícios podem variar muito. Finalmente, os autores nesses países precisam às vezes segurar o juízo no que respeita às despesas do adversário, antes de propor a ação. Por essas razões, pode-se indagar se a regra da sucumbência não erige barreiras de custo pelo menos tão substanciais, quanto às criadas pelo sistema americano (CAPPELLETTI E GARTH, 2002, p. 16-18).

Nesse sentido, afirma Morais que as reformas nessa primeira fase, conforme termo utilizado por Cappelletti e Garth (2002), visam a superação dos obstáculos decorrentes da pobreza, ou seja, hipossuficiência econômica. "Aos que não têm condições econômicas, devemse proporcionar informações e assistências extrajudicial, antes do ajuizamento, além de assistência judiciária e adequada representação legal, no curso do processo" (MORAIS, 1999, p. 88).

De qualquer forma, ainda afirmam Cappelletti e Garth (2002, p. 18), "torna-se claro que os altos custos, na medida em que uma ou ambas as partes devam suportá-los, constituem uma importante barreira ao acesso à justiça".

Afirma Vainer (2004) que, a assistência judiciária gratuita veio completar o rol dos denominados direitos individuais, tidos como fundamentais, previstos na Carta Política de 1988, especialmente no Título II, tornando-se, na última década, uma medida imperativa frente à quantidade de pessoas necessitadas. Ainda assim,

O princípio do aceso à justiça, ou da inafastabilidade da jurisdição, assim como o princípio de devido processo legal, é um superprincípio, informador de todo o processo civil brasileiro, visto que ele garante a todos que tenham o seu direito lesionado ou mesmo ameaçado, o acesso à justiça. Consiste na positivação que todos os indivíduos possuem de acionar o aparelho jurisdicional para a resolução 
de suas lides. E, de fato, tem-se que um direito somente será reconhecido por meio de um pronunciamento jurisdicional, a sentença (VAINER, 2004, p. 219).

A mais importante despesa individual para os litigantes consiste nos honorários advocatícios. Assim "qualquer tentativa realística de enfrentar os problemas de acesso deve começar por reconhecer esta situação: os advogados e seus serviços são muito caros" (CAPPELLETTI E GARTH, 2002, p. 18).

Nesse contexto, reportando-se rapidamente aos textos constitucionais brasileiros, afirma Morais (1999) que a expressão "Assistência Judiciária" apareceu, pela primeira vez na Carta de 1934, quando ainda não se tinha, nem mesmo, a garantia expressa do direito genérico de acesso ao Poder Judiciário; assim, as medidas que tendem remover ou atenua os obstáculos sofridos pelas pessoas carentes, para prover as despesas com a defesa de direitos, não são mais do que tentativas de proporcionar-lhes efetividade. Sabe-se muito bem,

[...] das despesas que envolvem uma demanda judicial: no mínimo custas processuais e honorários advocatícios. A isso podem se somar outros gastos, como com perícias, por exemplo. Como poderão esses brasileiros, que não ganham o suficiente nem para se alimentarem, custear um processo judicial? Esse o primeiro entrave - talvez o mais grave - ao efetivo acesso à justiça. Agrava-o ainda mais o fato de todas as partes envolvidas possuírem formalmente os mesmos direitos; igualdade essa que, em regime geral, não se concretiza em razão das diferenças sociais, econômicas e culturais existente entre as partes. Ou seja, todos são livres e iguais para buscarem a realização da justiça, mas de fato alguns são mais iguais do que outros. A situação será mais grave quanto maiores forem as diferenças entre as partes (MORAIS, 1999, p. 278).

Cappelletti e Garth (2002) salientam que "as pequenas causas" que envolvem somas relativamente pequenas são mais prejudicadas pela barreira dos custos.

Conforme Dinalli e Cintra (2005), a criação dos Juizados Especiais de Pequenas Causas, pela Lei $\mathrm{n}^{\mathrm{0}} 7.244 / 84$, introduziu no sistema processual brasileiro um rito diferenciado, com a finalidade de garantir o acesso da população mais carente ao judiciário, na busca de solução de conflitos de pequena monta ou de menor complexidade, assim estabelecendo novos critérios para o exercício da jurisdição.

Com relação ao tempo, afirmam Cappelletti e Garth (2002) que, em muitos países, as partes que buscam uma solução judicial precisam esperar dois ou três anos, ou mais, por uma decisão.

Os efeitos dessa demora, especialmente se considerados os índices de inflação, podem ser devastadores. E ela aumenta os custos para as partes e pressiona os economicamente fracos a abandonar suas causas, ou a aceitar acordos por valores muito inferiores àqueles a que teriam direito (CAPPELLETTI E GARTH, 2002).

A Convenção Europeia para a Proteção dos Direitos Humanos e Liberdades Fundamentais reconhece explicitamente, no artigo $6^{\circ}$, parágrafo $1^{\circ}$ que a Justiça que não cumpre sua função dentro de "um prazo razoável" é, para muitas pessoas, uma Justiça inacessível (CAPPELLETTI E GARTH, 2002).

Como segundo obstáculo, Cappelletti e Garth (2002) apontam as "possibilidades das partes" como ficou demonstrado por uma recente linha de pesquisa, de crescente importância, é ponto central quando se cogita da degeneração ou da garantia do acesso efetivo ". Ainda nesse sentido, 
Essa expressão, utilizada pelo Prof. Marc Galanter, repousa na "noção de que algumas espécies de litigantes [...] gozam de uma gama de vantagens estratégicas". Devemos reconhecer que o estudo das vantagens e desvantagens estratégicas está apenas começando e é difícil avaliá-las com precisão. No entanto, podemos não só isolar algumas das vantagens e desvantagens básicas para determinados litigantes, senão também, aventurar algumas hipóteses com base em pesquisas sociológicas recentes e altamente sugestivas (CAPPELLETTI E GARTH, 2002, p. 21).

Segundo Morais (1999), essa segunda onda se refere à pobreza organizada e às reformas necessárias à ruptura dessa tradicional postura individualista do processo civil.

Nesse sentido, afirma Morais

A necessidade social de se adotar formas de tutela capazes de romper o isolamento jurídico-legislativo dos indivíduos atingiu o seu ápice com as violações de massa, que incidiam sobre categorias inteiras de pessoas, especialmente os consumidores e os defensores da higidez ambiental. Os indivíduos passam então a manifestar, inconsciente, um certo desconforto sentido em virtude de não mais disporem de uma situação própria, típica [...], de tutela jurídica então oferecida pelo Ordenamento Jurídico e de não possuírem, sozinhos, força suficiente para se contrapor à potência dos empresários e dos grandes poluidores (MORAIS, 1999, p. 90).

Aptidão para reconhecer um direito e propor uma ação ou sua defesa, entendem Cappelletti e Garth (2002) que "capacidade jurídica" pessoal, se relaciona com as vantagens de recursos financeiros e diferenças de educação, meio e status social, é um conceito muito mais rico, e de crucial importância na determinação da acessibilidade da justiça. Ainda assim,

Num primeiro nível está a questão de reconhecer a existência de um direito juridicamente exigível. Essa barreira fundamental é especialmente séria para os despossuídos, mas não afeta apenas os pobres. Ela diz respeito a toda a população em muitos tipos de conflitos que envolvem direitos. Observou recentemente o professor Leon Mayhew: "Existe... um conjunto de interesses e problemas potenciais; alguns são bem; compreendidos pelos membros da população, enquanto outros são percebidos de forma pouco clara, ou de todo despercebidos". Mesmo consumidores bem informados, por exemplo, só raramente se dão conta de que sua assinatura num contrato não significa que precisem, obrigatoriamente, sujeitar-se a seus termos, em quaisquer circunstâncias. Falta-lhes o conhecimento jurídico básico não apenas para fazer objeção a esses contratos, mas até mesmo para perceber que sejam passiveis de objeção (CAPPELLETTI E GARTH, 2002, p. 23).

Esses obstáculos, afirmam Cappelletti e Garth (2002, p. 24), "têm importância maior ou menor, dependendo do tipo de pessoas, instituições e demandas envolvidas". Ainda que as relacione à "capacitação pessoal", é temerário que se as personalize. "Pessoas que procurariam um advogado para comprar uma casa ou obter o divórcio, dificilmente intentariam um processo contra uma empresa cuja fábrica esteja expelindo fumaça e poluindo a atmosfera. É difícil "mobilizar" as pessoas no sentido de usarem o sistema judiciário para demandar direitos não tradicionais". 
O terceiro obstáculo na posição de Cappelletti e Garth vem em relação aos interesses difusos. Os problemas especiais dos interesses "difusos" são interesses fragmentados ou coletivos, conforme Cappelletti e Garth (2002) tais como o direito ao ambiente saudável, ou à proteção do consumidor. O problema básico que eles apresentam com relação à razão de sua natureza difusa, é que, ou ninguém tem direito a corrigir a lesão a um interesse coletivo, ou o prêmio para qualquer indivíduo buscar essa correção e pequeno demais para induzi-lo a tentar uma ação.

Segundo Morais (1999), a partir desta dificuldade de organização, é que se procura viabilizar uma apropriada representação desses interesses difusos, em juízo, perante formas associativas de tutela, já que, atuando isolado o indivíduo jamais estará em condições de obter uma salvaguarda eficaz.

É nesse sentido que se realizam diversas reformas conceituais, então tradicionais no direito processual civil, com o fim de ampliar a legitimação para tais direitos/interesses, concedendo-a a órgãos públicos, privados, ou mesmo a representantes individuais autorizados a litigar em nome do grupo (MORAIS, 1999, p. 90).

Assim, afirmam Cappelletti e Garth (2002), conquanto como regra, a proteção privada de interesses difusos exija ação de grupo, é difícil assegurar que tal ação tenha lugar, se o próprio governo falhar.

A Defensoria Pública tem papel de relevante importância, tendo em vista que é encarado como a garantia de efetivação dos direitos fundamentais. É imprescindível para dar eficácia à democracia constitucional, já que a função jurisdicional representa a passagem da barbárie à civilização e à segurança jurídica. Assim, a preocupação em afiançar o efetivo acesso à justiça a todos, independentemente do seu grau de fortuna, é uma característica fundamental do Estado de Direito, sendo garantido a todos os cidadãos que buscam a tutela do Estado (MESQUITA, 2013).

A preocupação do Estado Brasileiro em oferecer condições para as pessoas necessitadas terem acesso à justiça teve um impulso a partir da Constituição de 1988, coincidentemente com o processo de redemocratização do país e o surgimento de novos direitos para o cidadão e dentre esses direitos, a garantia de assistência jurídica integral e gratuita aos que comprovarem insuficiência de recursos.

A Justiça, tida como um dos mais importantes valores da humanidade, é um ideal a ser alcançado. Mesmo sabendo que sua realização é absolutamente necessária para que a sociedade possa se desenvolver, respeitando a dignidade da pessoa humana, os valores sociais do trabalho e da livre iniciativa e o pluralismo político, como todo ideal, não se efetiva em toda a sua plenitude. Mas, sendo a Justiça um ideal, deve sempre ser buscada diante da ocorrência de uma lesão a algum direito, segundo o critério do justo e do equitativo, pois somente assim se tornará possível a máxima realização dos valores humanos (MONTEIRO, 2010).

A Defensoria Pública brasileira vem crescendo em autonomia e estrutura, qualificando e ampliando sua atuação a cada dia. Esse fortalecimento da instituição ocorre porque os Defensores e Defensoras Públicas atuam na ponta, na linha de frente, ao lado das pessoas que precisam da justiça e não podem pagar um advogado.

É imprescindível a compreensão de que há diferenças fundamentais entre a advocacia dativa e a Defensoria Pública: enquanto a primeira resume-se a prestar assistência judiciária, múnus público decorrente da atividade profissional do advogado, a segunda tem compromisso institucional legal de assegurar o pleno acesso à Justiça e seu papel transformador, prestando assistência jurídica, judicial e extrajudicial, integral e gratuita aos necessitados (MONTEIRO, 2010). 
Tal forma de trabalhar acaba por resultar num filtro profissional, permanecendo na instituição aqueles que realmente têm vocação para trabalhar próximo da comunidade. Do trabalho abnegado, e contato direto com a população, não haveria outra consequiência que não se legitimar fortemente perante a sociedade. Por tudo isso, os defensores públicos passaram a desempenhar um papel político fundamental na consolidação da democracia e na garantia dos direitos fundamentais (CAMPOS, 2011). 


\section{MEDIAÇÃO}

A Mediação ${ }^{5}$ constitui uma forma dita alternativa e não adversarial para a solução dos conflitos (CARVALHAL, 2006), uma vez que não está inserida no sistema tradicional de justiça, em que há a interferência do Estado, através das demandas, e são oferecidas às partes soluções impositivas (sentenças), caso as mesmas não consigam chegar a uma definição através das conciliações (acordos), também institutos alternativos, mas previstos na legislação processual.

Souza (2004) traz um conceito de mediação em que diz que a mediação é um mecanismo para a solução de conflitos através da gestão do mesmo (sic) pelas próprias partes, para que estas construam uma decisão rápida, ponderada, eficaz e satisfatória para os envolvidos. mediação é

Buscando ainda conceituar a mediação, Eliana Riberti Nazareth (2001) diz que a

[....] um método de condução de conflitos, voluntário e sigiloso, aplicado por um terceiro neutro e especialmente treinado, cujo objetivo é restabelecer a comunicação entre pessoas que se encontram em um impasse, ajudando-as a chegar a um acordo (NAZARETH, 2001, p. 71).

\section{Para Vasconcelos que}

[...] mediação é um meio geralmente não hierarquizado de solução de disputas em que duas ou mais pessoas, com a colaboração de um terceiro, o mediador que deve ser apto, imparcial, independente e livremente escolhido ou aceito -, expõem o problema, são escutadas e questionadas, dialogam construtivamente e procuram identificar os interesses comuns, opções e, eventualmente, firmar um acordo (VASCONCELOS, 2008, p. 36).

Salientam Sampaio e Braga Neto que os métodos para solução dos conflitos de forma pacífica e sem a intervenção da justiça estatal nasceram numa "tendência liberal em todo o mundo" em que se tem a

[...] retirada cada vez maior do Estado dos assuntos de interesse dos particulares, situando-se no bojo do reconhecimento da plenitude do cidadão como objeto de deveres e direitos, que por si só pode melhor administrar, transformar ou resolver seus próprios conflitos (SAMPAIO; BRAGA NETO, 2007, p. 9).

Calmon traz orientações do Centro para Resolução de Disputas do Instituto de Administração Judicial dos Estados Unidos da América em seu livro Fundamentos da Mediação e da Conciliação em que diz que a

[...] mediação é um termo utilizado para descrever um conjunto de práticas elaboradas para ajudar as partes na controvérsia, caracterizando-se pela participação de um terceiro imparcial que ajuda as artes a comunicar-se e a

5 "O verbolatinomediare, quesignificamediar, dividiraomeio, interviroucolocar-se no meio, deuorigemaotermomediação".

Revista de Direito Brasileira | São Paulo, SP | v. 20 | n. 8 | p. 146-173 |Mai./Ago. 2018 
realizar escolhas voluntárias em um esforço para resolver o conflito (CALMON, 2008, p. 120-121).

\section{Já Grinover diz que}

[...] a mediação assemelha-se à conciliação: os interessados utilizam a intermediação de um terceiro, particular, para chegarem à pacificação de seu conflito. Distingue-se dela somente porque a conciliação busca sobretudo o acordo entre as partes, enquanto a mediação objetiva trabalhar o conflito, surgindo o acordo como mera conseqüência. Trata-se mais de uma diferença de método, mas o resultado acaba sendo o mesmo (CINTRA, GRINOVER, DINAMARCO, 2005, p. 34).

A mediação, por ter como foco o conflito em si, tende a ter uma efetividade muito maior do que a conciliação na resolução do impasse, uma vez que esta última pretende, em muitos casos, alcançar somente o acordo sem resolver o problema.

Para melhor entendimento, a palavra mediação vem do latim, do verbo mediare, que quer dizer intervir ou se colocar no meio. Apresenta sua definição como sendo um método de condução de conflitos, aplicado por um terceiro neutro e especialmente treinado, cujo objetivo é restabelecer a comunicação produtiva entre as pessoas, que se encontram em momento de impasse, contribuindo para que celebrem um acordo, se esse for o caso (NAZARETH, 2001).

Na concepção de Vezzulla, entende-se por mediação:

[...] a técnica privada de solução de conflitos que vem demonstrando, no mundo, sua grande eficiência nos conflitos interpessoais, pois com ela, são as próprias partes que acham as soluções. O mediador somente as ajuda a procurá-las, introduzindo, com suas técnicas, os critérios e os raciocínios que lhes permitirão um entendimento melhor (VEZZULLA, 1998, p. 15-16).

A referida técnica constitui-se como uma forma, dita alternativa e não adversarial, para a solução dos conflitos, uma vez que não se insere no sistema tradicional de justiça, com interferência do Estado, encaminhadas por meio das demandas, cujas soluções impositivas (sentenças) são oferecidas às partes nas situações em que as mesmas não chegam a conciliações (acordos) previstos na legislação processual (NAZARETH, 2001).

$\mathrm{O}$ artigo $1^{\circ}$ da Lei 13.140/2015 e seu parágrafo único destaca que:

Art. 10 - Esta Lei dispõe sobre a mediação como meio de solução de controvérsias entre particulares e sobre a autocomposição de conflitos no âmbito da administração pública.

Parágrafo único. Considera-se mediação a atividade técnica exercida por terceiro imparcial sem poder decisório, que, escolhido ou aceito pelas partes, as auxilia e estimula a identificar ou desenvolver soluções consensuais para a controvérsia.

A percepção de que a mediação é um instrumento informal, que atende a vontade das partes, tendo um terceiro, mediador, papel fundamental de auxiliar as partes conflitantes. Sua prática não é moderna, mas uma prática milenar, utilizada pela primeira vez na China, onde 
utilizar um tribunal para resolver problemas pessoais era contra a moral e os bons costumes, como enfatiza Nazareth (2001).

Sempre pensando que a mediação existe para atender necessidades e interesses dos indivíduos, os Estados Unidos iniciaram sua utilização em 1970, após perceberem o enfraquecimento das decisões judiciais na vida social, para a lide prospectiva de população local. Seu intuito é a convivência duradoura entre os indivíduos, de maneira que eles próprios decidam e articulem as demandas conflituosas (AZEVEDO, 2015).

Salientam Sampaio e Braga Neto que os métodos para solução dos conflitos de forma pacífica e sem a intervenção da justiça estatal nasceram numa "tendência liberal em todo o mundo" em que se tem a

[...] retirada cada vez maior do Estado dos assuntos de interesse dos particulares, situando-se no bojo do reconhecimento da plenitude do cidadão como objeto de deveres e direitos, que por si só pode melhor administrar, transformar ou resolver seus próprios conflitos (SAMPAIO; BRAGA NETO, 2007, p. 9).

Calmon traz orientações do Centro para Resolução de Disputas do Instituto de Administração Judicial dos Estados Unidos da América, em seu livro Fundamentos da Mediação e da Conciliação, no qual escreve que a

[...] mediação é um termo utilizado para descrever um conjunto de práticas elaboradas para ajudar as partes na controvérsia, caracterizando-se pela participação de um terceiro imparcial que ajuda as artes a comunicar-se e a realizar escolhas voluntárias em um esforço para resolver o conflito (CALMON, 2008, p. 120-121).

Já para Grinover:

[...] a mediação assemelha-se à conciliação: os interessados utilizam a intermediação de um terceiro, particular, para chegarem à pacificação de seu conflito. Distingue-se dela somente porque a conciliação busca sobretudo o acordo entre as partes, enquanto a mediação objetiva trabalhar o conflito, surgindo o acordo como mera conseqüência. Trata-se mais de uma diferença de método, mas o resultado acaba sendo o mesmo (GINOVER et al, 2008, p. 34).

No Brasil, surgiu o Projeto de Lei $\mathrm{n}^{\circ}$ 4.827/1998, trazendo a ideia da Mediação conjugada com algumas disposições específicas, caminhando ainda pela Câmara dos Deputados até 2002, chegando ao Senado Federal como Projeto de Lei Complementar (PLC), recebendo o número 94/2002. Após discussão, passou-se a fazer parte da chamada "Reforma do Poder Judiciário", com a Emenda Constitucional 45/2004. Dessa forma, o Governo resolveu a instituiu pela Emenda $n^{\circ} 1$ da Comissão de Constituição e Justiça-CCJ, em 2006, que até o presente, encontra-se paralisada em sua operacionalidade.

O Supremo Tribunal Justiça inseriu no projeto do novo Código de Processo Civil (CPC), em vários artigos de lei, a necessária aparência da Mediação, como a melhor ou senão única forma de se remediar o maior mal, ou seja, a morosidade dos processos, até então causada pela desatenção do Judiciário para com a sociedade. 
À legislação específica soma-se o novo CPC, Lei nº 13.105/2015, que entrando em vigor antes mesmo dessa, janeiro de 2016, sendo apresentada como Lei $\mathrm{n}^{\mathbf{0}} 13.140$ de 26 de junho de 2015. Toda legislação incorpora esta poderosa ferramenta de mobilização social, que é a mediação judicial e extrajudicial, "Dispõe sobre a mediação entre particulares como meio de solução de controvérsias e sobre a autocomposição de conflitos no âmbito da administração pública [...]". O método autocompositivo é assim chamado porque as partes é que decidem; é um método de resolução de conflitos em que as necessidades, os desejos das partes é que são levados em conta.

Nessa nova proposta desenvolvimentista, a pessoa humana protagonista, ou seja, o mediador, deverá ser o responsável pela promoção das ações nos locais, a fỉm de colaborar efetivamente para que se,

[...] permita abrir nuevas líneas de acción, unDesarrollo a Escala Humana. Tal desarrollo se concentra y sustenta enlasatisfacción de lasnecesidades humanas fundamentales, enlageneración de niveles crecientes de auto-dependencia y enlaarticulaciónorgánica de los seres humanos conlanaturaleza y latecnología, de losprocesosglobalesconloscomportamientoslocales, de lopersonalconlo social, de laplanificaciónconlaautonomía y de lasociedad civil conel Estado (MAXNEEF et al, 2010, p 12).

De acordo com o teórico, o desenvolvimento humano, que está diretamente relacionado à ampliação das habilidades e potencialidades do ser humano, se torna um fator importante para promover a melhoria da realidade individual e social, propiciando, assim, uma mudança substancial em seu comportamento coletivo.

A conciliação aproxima-se da mediação, com a diferença de que o conciliador não age de forma tão passiva ou neutra como os mediadores. O conciliador trabalha em especial nas proposições dos contendores e não em seus reais e efetivos interesses que, na maioria das vezes, se mostram ocultos (COSTA, 2002).

Na técnica da conciliação, as partes se reúnem por, no máximo dois dias, auxiliadas por uma terceira pessoa que, além de aproximar as partes, opina, sugere e aponta soluções passíveis para o conflito, sendo seu procedimento informal, estabelecendo elo de ligação entre as partes e a pendência posta (COSTA, 2002).

A diferença entre a mediação e a conciliação repousa no fato de o mediador não interfere nas negociações, servindo apenas de elo; na conciliação, o mediador dá sugestões, opiniões e apresenta possíveis soluções para o conflito (COSTA, 2002).

O novo Código de Processo Civil estabelece que tribunais devam criar centros judiciários de solução consensual de conflitos, que sendo responsáveis pela realização de sessões e audiências de conciliação e mediação e pelo desenvolvimento de programas destinados a auxiliar, orientarão e estimularão a autocomposição, calcada nos princípios da independência, da imparcialidade, da autonomia da vontade, da confidencialidade, da oralidade, da informalidade e da decisão informada.

Ressalta-se, ainda, que, o Poder Público é parte em mais de 50\% dos processos judiciais em trâmite no país, por isso, a inclusão da mediação para solução de conflitos levou em conta essa realidade (SILVA, 2004).

Apesar de admitir a mediação e a aplicação de técnicas negociais, com o objetivo de proporcionar um ambiente favorável à autocomposição, o novo CPC não determina quais sejam essas técnicas, ou qual procedimento o mediador deverá utilizar, assim como também nada menciona sobre quais tipos de conflitos podem ser alvo da mediação, apenas estabelecendo a livre autonomia dos interessados, inclusive no que diz respeito à definição das regras 
procedimentais. A lei determina que deverá haver um cadastro nacional de mediadores e um cadastro nos tribunais de justiça, o qual será mantido em sigilo.

Sobre o método, Fisher et al. (2005) estabelece um percurso para a mediação composto de quatro passos:

a) separar as pessoas dos problemas;

Qualquer método de negociação pode ser julgado imparcialmente por três critérios: deve produzir um acordo sensato, se houver possibilidade de acordo; deve ser eficiente; e deve aprimorar, ou, pelo menos, não prejudicar o relacionamento entre as partes. (Um acordo sensato pode ser definido como aquele que atende aos interesses legítimos de cada uma das partes na medida do possível, resolve imparcialmente os interesses conflitantes, é duradouro e leva em conta os interesses da comunidade) (FISCHER et al, 2005, p. 22).

O importante não são as pessoas, mas os problemas que elas enfrentam. Dessa forma, a mediação deve ajudar a conseguir para ambas as partes boas vantagens e soluções que as satisfaçam, de forma que nenhuma delas saia perdendo.

b) concentração total nos interesses das partes e não na posição que ocupam;

A forma mais comum de negociação, [...] depende de se assumir sucessivamente — e depois, abandonar — uma sequência de posições. Tomar posições [...], atende a alguns fins úteis numa negociação. Diz ao outro lado o que você quer; fornece um esteio nas situações incertas e pressionantes; e pode acabar por produzir os termos e um acordo aceitável. Entretanto, pode-se chegar a esses fins de outras maneiras. E a barganha posicional deixa de atender aos critérios básicos de produzir um acordo sensato, de modo eficiente e amistoso. [...] A barganha de posições cria estímulos que paralisam a resolução. Na barganha posicional, você procura aumentar a probabilidade de que qualquer acordo atingido lhe seja favorável, começando numa posição extremada, aferrando-se obstinadamente a ela, iludindo a outra parte quanto a suas verdadeiras opiniões e fazendo pequenas concessões, apenas na medida necessária, para manter a negociação em andamento. O mesmo se aplica ao outro lado. Cada um desses fatores tende a interferir na pronta obtenção de um acordo. Quanto mais extremadas as posições iniciais e menores as concessões, maiores serão o tempo e o esforço despendidos para descobrir se o acordo é ou não possível (FISCHER et al, 2005, p. 24).

Não interessa qual a posição que as partes ocupam, mas sim, seus interesses. Não é o fato de uma das partes querer uma coisa e a outra querer o contrário; é o interesse de ambas que deve receber toda atenção, para que as duas partes saiam satisfeitas.

c) criação de opções de ganhos mútuos;

O mediador deve criar várias chances de ganhos para ambas as partes, com a solução encontrada, de forma a tornar mais atraente a solução do que o problema, fazendo com que ambas as partes entendam que saíram com vantagens.

d) Perseverar em critérios objetivos.

O mediador precisa ser prático, ter juízo crítico e buscar se preparar para mediar uma situação de conflito, estudando bem o problema e as possíveis soluções existentes. Não se deve ir despreparado para uma medição. A análise de cada caso concreto é de grande valia para encontrar soluções amigáveis para ambos os lados. 
De acordo Ghisleni e Spengler (2011), o mediador trabalha para o processo e não para uma das partes nomeadamente, ou seja, um processo que tem por finalidade tão somente a satisfação pessoal de um em prejuízo ao outro não terá sucesso, visto que a mediação tende à resolução do conflito de forma pacífica, levando a concluir que no processo em que haja mediação não haverá ganhador/perdedor ou procedência/improcedência, mas sim, duas partes que entrarão em consenso e decidirão a lide conforme sua vontade.

Nesses termos, "a virtude do mediador é aquela do estar no meio, de compartilhar, e até mesmo do "sujar as mãos". O mediador que se coloca como tal deixa de ser mediador e assume uma posição estranha, super partes, incapaz de assumir o litígio como o elemento comum das partes, que é também o meio simbólico a ser transformado e reutilizado, para reativar a capacidade comunicativa (GHISLENI E SPENGLER, 2011, p. 49).

É imperativo que haja aceitação dos litigantes, de modo a permitir que outra pessoa entre na disputa para ajudar na chegada de uma definição. Todavia, isso não significa necessariamente que as partes "recebam muitíssimo bem o envolvimento do mediador e estejam dispostas a fazer exatamente o que ele diz", mas sim, que "aprovam a presença do mediador e estão dispostas a ouvir e considerar seriamente suas sugestões" (MOORE, 1998, p. 28).

Como a mediação é praticada em diversas situações (fóruns, conflitos, culturas), o tipo de relacionamento que o intermediário tem com as partes influencia o tipo de interferência que é utilizada para ajudá-las. Silva (2004) garante que o mediador inaugura um novo tipo de profissional, porquanto não é um advogado, nem psicólogo ou médico, além de dever ser imparcial e investigar "para conhecer os reais interesses". Além disso, só as próprias partes sabem o que é melhor para elas e, portanto, ele deve falar para que elas falem e se questionem (GHISLENI E SPENGLER, 2011).

Silva (2004, p. 107) também sustém que a mediação é um procedimento rápido, no qual ocorre "a composição de interesses e não a definição de direitos", e é composto de oito estágios, quais sejam: iniciação (quando as partes optam pela mediação e escolhem o mediador), preparação (informação às partes sobre as características da disputa e resultados que almejam), introdução (esclarecimento do procedimento e aceitação das partes), declaração do problema (discussão aberta das controvérsias), esclarecimento do problema (especificação do problema pelo mediador), geração e avaliação de alternativa(s) (o mediador estimula as partes a se questionarem, conduzindo-as à produção de alternativas), seleção de alternativa(s) (o mediador aponta as soluções inviáveis e praticáveis) e acordo (esclarecimento dos termos do acordo e a confirmação da aceitação das partes). Pode haver a necessidade de retornar a alguma etapa anterior para maiores esclarecimentos, que deve ser percebida e efetivada pelo mediador.

A finalização do procedimento de mediação compreende a formalização do acordo. Esta fase necessita da concretização de duas etapas: a "implementação dos procedimentos de indução ao compromisso que vão melhorar a probabilidade de cumprimento", bem como "alguma forma de atividade simbólica de encerramento do conflito" (MOORE, 1998, p. 268).

Para Ghisleni e Spengler (2011), o acordo celebrado entre os litigantes deve ser o mais realista possível para conseguir satisfazê-los ao máximo, prevenindo complicações futuras e possibilitando maior durabilidade. Assevera a importância da elaboração do acordo em uma linguagem fácil e compreensível, contendo todas as especificações decididas pelas partes. A mediação é um procedimento capaz de resolver problemas, porém é, também, potencialmente, uma oportunidade para estabelecer, definir, edificar ou terminar relacionamentos. Tanto os aspectos da mediação referentes à resolução de problemas quanto à definição de relacionamentos ocorrem no contexto da discussão de questões e interesses que podem ser de natureza essencial, processual ou psicológica.

O novo CPC estabelece que cada tribunal do país pode criar um cadastro próprio de conciliadores e mediadores, mas esses, se forem advogados, estarão impedidos de exercer sua função no tribunal em que mediar. Ainda assim, as partes podem escolher um mediador que não 
necessariamente esteja cadastrado. Haverá o mediador ou conciliador voluntário, mas também haverá mediadores e conciliadores que receberão por seu trabalho, conforme parâmetros estabelecidos pelo Conselho Nacional de Justiça.

\section{CONSIDERAÇÕES FINAIS}

Embora o Poder Judiciário tenha como principal objetivo a celeridade dos atos processuais, incentivada pela redução dos prazos, a simplificação dos procedimentos e a incessante busca pela conciliação entre as partes, o que se observa é que o número de demandas judiciais vem crescendo consideravelmente a cada ano, proporcionando o acúmulo do número de processos nas Varas e Juizados do país, o atraso nas pautas de audiência e a consequente insatisfação do jurisdicionado.

Com isso, a prestação de uma tutela jurisdicional de qualidade fica prejudicada, uma vez que o principal objetivo do jurisdicionado, ao ingressar com uma demanda judicial, não está sendo alcançado, qual seja, a imediata resolução do conflito. Devido à enorme carga processual acumulada nos últimos anos, o judiciário não está sendo capaz de proporcionar às partes uma tutela jurisdicional de qualidade, célere e eficaz ao mesmo tempo.

A utilização de meios alternativos de resolução de conflitos, em especial a mediação, pode auxiliar o judiciário a diminuir a carga processual, garantindo às partes celeridade na prestação jurisdicional, sigilo do procedimento, maior informalidade, baixo custo, além da possibilidade de escolher um julgador de sua confiança para intermediar o conflito.

Por se tratar de um meio extrajudicial de resolução de conflitos, a mediação ainda encontra resistência por parte de alguns doutrinadores no que tange a sua efetiva aplicação no âmbito da Justiça Comum e Especializada. A incompatibilidade entre o objeto da mediação e a natureza de alguns direitos em litígio e a violação de princípios constitucionais como o da inafastabilidade do Poder Judiciário, do duplo grau de jurisdição, do contraditório e da ampla defesa e do devido processo legal, são alguns dos argumentos apresentados em desfavor da mediação.

Neste aspecto, restaria impossibilitada a efetiva aplicação da mediação no âmbito extrajudicial para dirimir os conflitos de interesse. Entretanto, esse entendimento vem sendo mitigado aos poucos pela doutrina especializada e por decisões reiteradas dos Tribunais de todo país, que tem se posicionado a favor da utilização da mediação, reconhecendo o presente instituto como válido para resolver os conflitos de interesse em sociedade.

É importante ressaltar que a mediação constitui uma opção das partes e, nesse sentido, tal escolha não deve ser considerada como renúncia à jurisdição estatal. Pelo contrário, a existência de meios extrajudiciais de resolução de conflitos permite ao jurisdicionado optar pelo procedimento mais eficaz, seja ele público ou privado, sem, contudo, abdicar do sistema jurisdicional estatal para resolver os litígios decorrentes das relações sociais.

O jurisdicionado tem a faculdade de levar a demanda judicial à apreciação do órgão jurisdicional que melhor lhe aprouver, desde que o este órgão atenda aos fins sociais do processo, julgando a lide de acordo com os preceitos constitucionais e sempre respeitando o devido processo legal.

Assim, a mediação surge como uma alternativa de jurisdição, reconhecida pela Constituição Federal como instrumento legal capaz de dirimir os conflitos de interesse, uma vez frustrada eventual negociação entre partes litigantes. O instituto da mediação, entretanto, ainda é pouco utilizado, ou mesmo desconhecido, pela maioria da população, fruto principalmente da falta de informação e de incentivo na utilização de meios extrajudiciais de resolução de contendas. 
A utilização de meios alternativos como a mediação serve para, se não resolver, pelo menos tentar minimizar o colapso da via jurisdicional de solução de conflitos agravado pelo aumento crescente do número de demandas nas diversas esferas do Poder Judiciário.

\section{REFERÊNCIAS}

AZEVEDO, André Gomma de (Org.) et al. Manual de mediação judicial. Brasília: Conselho Nacional de Justiça, 2015

BARCELlOS, Ana Paula de. A eficácia jurídica dos princípiosconstitucionais: O princípio da dignidade da pessoa humana. 2 ed., amplamenterev.eatual. Rio de Janeiro: Renovar, 2008.

BOBBIO, Norberto. A era dos Direitos. Rio de Janeiro: Campus, 1992.

BRASIL. DECRETO no 19.841, de 22 de outubro de 1945. Disponívelem: http://www.planalto. gov.br/ccivil_03/decreto/1930-1949/d19841.htm. Acessoem 12/07/2016.

. Superior Tribunal de Justiça. AgRg no REsp 755429 / PR. AGRAVO REGIMENTAL NO RECURSO ESPECIAL 2005/0089854-4.

Supremo Tribunal de Justiça. AO 1.531-AgR, voto da Min. CármenLúcia, julgamentoem 3-6-09, Plenário, DJE de 1º-7-09.

CALMON, Petrônio. Fundamentos da Mediação e da Conciliação. Rio de Janeiro: Forense, 2008

CAMPOS, Marcelo Vieira. Dia para comemorar: Defensoria Pública é essencialaoacesso à Justiça. Revista Consultor Jurídico, 18 de maio de 2011.

CAPPELLETTI, Mauro, GARTH, Bryant. Acesso à justiça. Porto Alegre: Fabris, 2002.

CARVALHAL, Eugenio do et al. Negociação e administração de conflitos. Rio de Janeiro: FGV, 2006.

CINTRA, Antonio Carlos Araujo; GRINOVER. Ada Pellegrini; DINAMARCO, Cândido Rangel. Teoriageral do processo. 26 ${ }^{\mathrm{a}}$ ed. São Paulo: Malheiros, 2010.

COMPARATO, Fabio Konder. A Afirmação histórica dos Direitos Humanos. 6 ed. São Paulo: Saraiva 2008.

DALLARI, Dalmo de Abreu. Elementos da teoriageral do estado. 24. ed. São Paulo: Saraiva, 2003

DE VITTO, Renato Campos Pinto; CASTRO, André Luís Machado. A Defensoria Pública como Instrumento de Consolidação da Democracia. APADEP - Associação Paulista de Defensores Públicos. s/d. Disponívelem: http://www.apadep.org.br/artigos/a-defensoria-publica-comoinstrumento-de-consolidacao-da-democracia/\#comment-1064. Acessoem 12/07/2016. 
DINALLI, Aparecida; CINTRA, Jorge Antonio Conti. Do acesso à justiça: JuizadosEspeciaisCíveis. Revista de Direito constitucional e internacional, São Paulo: Revista dos Tribunais, v. 13, n. 51, p. 25-43, abril/jun. 2005.

FERREIRA Filho, ManoelGonçalves. Direitos Humanos Fundamentais. 4. ed. São Paulo: Saraiva, 2000.

FISCHER, Roger. Como chegaraosim: negociação de acordossemconcessões. Tradução Vera Ribeiro \& Ana luiza Borges. 2 ed. revisada e ampliada. Rio de Janeiro: Imago Ed., 2005.

GARCEZ, J. M. R. Contratos internacionaiscomerciais: planejamento, negociação, solução de conflitos, cláusulas especiais, convençõesinternacionais. São Paulo: Saraiva, 1994 COSTA, Nilton César Antunes da. Poderes do árbitro: de acordocom a Lei 9.307/1996. São Paulo: Revista dos Tribunais, 2002.

GHISLENI, Ana Carolina; SPENGLER, Fabiana Marion. Mediação de conflitos a partir do Direito Fraterno. Santa Cruz do Sul: EDUNISC, 2011.

GRAU, Eros Roberto; CUNHA, Sérgio Sérvulo da. Estudos de direito constitucional em homenagem a José Afonso da Silva. São Paulo: Malheiros, 2003.

GRINOVER, Ada Pellegrini et al. Mediação e gerenciamento do processo: revolução da prestaçãojurisdicional: guiaprático para instalação do setor de conciliação e mediação. São Paulo: Atlas, 2008.

INACOM - Instituto Internacional de Arbitragem, Mediação e Conciliação. Mecanismos extrajudiciais de solução de conflitos. Apostila II. Belo Horizonte: INACOM, 2004.

KANT, Immanuel. Fundamentação da metafísica dos costumes. Os pensadores. Tradução Paulo Quintela. São Paulo: Abril Cultural, 1980.

KARNAL, Leandro. Estados Unidos: da colônia à Independência. 5 ed. São Paulo: Conexto, 1999.

MAX-NEEF, Manfred; ELIZALDE, Antonio; HOPENHAYN, Martín. Desarrollo a escala humana: Opciones para el futuro. Madrid, marzo de 2010. Disponívelem:http://habitat.aq.upm.es/deh/adeh.pdf. Acessoemfev/2016

MESQUITA, Maíra de Carvalho Pereira. Acesso à Justiça e Defensoria Pública. Revista JusNavigandi, Teresina, ano 18, n. 3491, 21 jan. 2013. Disponívelem: https://jus.com.br/artigos/23504/acesso-a-justica-e-defensoria-publica. Acessoem: jul 2016.

MICELI, Paulo. As revoluções Burguesas. 18 ed. São Paulo: Atual, 1994.

MONTEIRO, Fagner César Lobo. Breves considerações acerca do papel da defensoria pública naevolução do acesso à Justiça. In: Âmbito Jurídico, Rio Grande, XIII, n. 78, jul 2010. Disponívelem:

http://www.ambitojuridico.com.br/site/index.php?artigo_id=8033\&n_link=revista_artigos_leitura. Acessoem 2016. 
MOORE, Christopher W. O processo de mediação: estratégiaspráticas para a resolução de conflitos. Porto Alegre: Artmed, 1998.

MORAIS, José LuizBolzan de. Mediação e arbitragem: alternativas à jurisdição. Porto Alegre: Livraria do advogado, 1999.

NAZARETH, Eliana Riberti. Mediação O Conflito e a Solução. São Paulo: Arte Paubrasil, 2009.

Psicanálise e Mediação - Meiosefetivos de ação. Revista do Advogado, São Paulo; Associação dos Advogados de São Paulo, nº 62, p. 55, março de 2001.

RABINOVICH-BERKMAN, Ricardo David. Derechos Humanos. Una introducción a su naturaliza y a sua historia. $1^{\mathrm{a}}$ ed. Buenos Aires: Quorum, 2007.

SAMPAIO, Lia Regina Castaldi; NETO, Adolfo Braga. O que é mediação de conflitos. São Paulo: Brasiliense, 2007.

SARLET, Ingo Wolfgang. As Dimensões da dignidade da pessoa humana: construindoumacompreensão jurídico-constitucional necessária e possível. Porto Alegre: Livraria do Advogado, 2005.

SILVA, João Roberto da. A mediação e o processo de mediação. São Paulo: Paulistanajur, 2004.

SILVA, José Afonso. Curso de direito constitucional positivo. 8. ed. São Paulo: Malheiros, 1992.

SOUZA, Zoraide Amaral de. Arbitragem - Conciliação - Mediação nos ConflitosTrabalhistas. São Paulo: LTr, 2004.

STRECK, LênioLuiz, MORAIS, José Luis Bolzan de. Ciência política e teoriageral do estado. 3. ed. Porto Alegre: Livraria do Advogado, 2003.

VAINER, Bruno Zilberman. AssistênciaJudiciária Gratuita: Umdesafio de nosso tempo. Revista de Direito Constitucional e Internacional, São Paulo: Revista dos Tribunais, v. 12, n. 48, p. 213243, jul/set. 2004.

VASCONCELOS, Carlos Eduardo de. Mediação de Conflitos e Práticas Restaurativas. São Paulo: Método, 2008.

VEZZULLA, Juan Carlos. Teoria e Prática da Mediação. Paraná: Instituto de Mediação e Arbitragem do Brasil, 1998. 